\title{
KEEFEKTIFAN PELATIHAN PENYUSUNAN BAHAN AJAR BERBASIS LECTORA DI DINAS PENDIDIKAN PEMUDA DAN OLAHRAGA SLEMAN
}

\author{
Tuginem, Muhyadi \\ SDN Tlacap Sleman, Universitas Negeri Yogyakarta \\ ugikwae@gmail.com, muhyadi@uny.ac.id
}

\begin{abstract}
Abstrak
Penelitian ini bertujuan untuk mengetahui keefektifan penyelenggaraan pelatihan penyusunan bahan ajar berbasis lectora di Dinas Dikpora Kabupaten Sleman. Penelitian ini adalah penelitian evaluasi dengan pendekatan kuantitatif dan berdasarkan konsep Kirpatrick dengan empat tingkatan yaitu: (1) evaluasi tingkat reaksi; (2) evaluasi tingkat belajar; (3) evaluasi tingat perilaku, dan (4) evaluasi tingkat dampak. Subjek penelitian adalah guru TK, SD, SMP, SMA, dan SMK. Teknik pengumpulan data yang digunakan adalah angket dan dokumentasi. Analisis data menggunakan analisis deskriptif. Hasil penelitian ini menunjukkan bahwa (1) komponen penyelenggaraan pelatihan penyusunan bahan ajar berbasis lectora dengan rata-rata 56,55 berada dalam kategori efektif $(45,01-58,50)$, artinya tanggapan dari peserta dalam hal penyelenggaraan pelatihan baik untuk diselenggarakan oleh lembaga tetapi belum optimal; (2) komponen kemampuan fasilitator pelatihan penyusunan bahan ajar berbasis Lectora dengan rata-rata 64,79 berada dalam kategori sangat efektif $(>61,75)$, artinya peserta mempunyai persepsi yang sangat baik terhadap perilaku fasilitator dalam mengajar dan melatih peserta selama pelatihan; (3) komponen hasil belajar peserta pelatihan penyusunan bahan ajar berbasis lectora dengan rata-rata 75,44 berada dalam kategori efektif $(65,01-84,50)$, artinya bahan ajar tersebut dapat digunakan atau diimplementasikan dalam proses belajar mengajar di sekolah masing-masing; 4) komponen pemenuhan kompetensi pedagogik pelatihan penyusunan bahan ajar berbasis lectora dengan rata-rata 24,10 berada dalam kategori sangat efektif $(>22,75)$, artinya standar kompetensi pedagogik guru terpenuhi.
\end{abstract}

Kata Kunci:pelatihan, penyusunan bahan ajar, lectora

\section{THE EFFECTIVENESS OF THE TRAINING FOR CONSTRUCTING LECTORA-BASED INSTRUCTIONAL MATERIALS AT THE BRANCH OFFICE OF EDUCATION, YOUTH, AND SPORTS IN SLEMAN}

\begin{abstract}
This research aimed at revealing the effectiveness of the training for constructing lectora-based instructional materials at the Branch Office of Education, Youth, and Sports in Sleman. This study is evaluation research with the quantitative approach using the. Kirpatrick concept using the four levels: (1) evaluating reactions level; (2) evaluating learning level; (3) evaluation behavior level, and (4) evaluating result level. The research subjects were teachers of kindergartens, junior high schools, senior high schools, and vocational high schools. The data were obtained through a questionnaire and documentation. The data analysis used the descriptive analysis. The result shows that (1) the implementation of the training component of the effectiveness of the training for constructing lectora based instructional materials at the Branch Office of Education, Youth, and Sports in Sleman has got the average score of 56.55 which is in an effective category (45.01-58.50) and it means that the participants responses are good to conduct any organization although it is not optimal, (2) the component of facilitators, competence in effectiveness of the training for constructing lectora-based instructional materials at the Branch Office of Education, Youth, and Sports in Sleman gains the average score of 64.79 which is in very high category $(>61.75)$ and means that the participants have a good perception of the facilitators performance during the training process; (3) the component of participant's learning achievement is an effective category (65.01-84.50) and it means that those materials are ready to be applied in the teaching and learning process in schools; (4) the component of pedagogical competence in effectiveness of the training for constructing lectora-based instructional materials at the Branch Office of Education, Youth, and Sports in Sleman is 24.10 which is in an effective category (>22.75), and it means that teacher's pedagogical competence is met.
\end{abstract}

Keywords: training, instructional materials, lectora 


\section{Pendahuluan}

Guru sebagai tenaga kependidikan dalam menjalankan fungsi pendidikan dilihat sebagai totalitas yang satu sama lain secara sinergi memberikan sumbangan terhadap proses pendidikan pada tempat di mana mereka memberikan pelayanan, dengan titik tekan tenaga kependidikan di lembaga pendidikan persekolahan. Keberhasilan dalam upaya memberikan pelayanan optimal guru terhadap peserta didik dapat dilihat dari penguasaan materi pembelajaran yang disampaikan secara efektif dan kehadirannya diterima oleh anak didik secara ikhlas. Guru juga mampu menjadi manajer belajar yang baik, sekaligus terus belajar melalui proses pembelajaran yang dilakukannya (learning from teaching processes), bahkan belajar dari peserta didik.

Merujuk pada kondisi tersebut, jumlah guru yang begitu besar merupakan sumber daya pendidikan yang perlu penangan optimal. Sumber daya manusia dalam hal ini guru adalah aset organisasi yang paling penting karena mempengaruhi efesiensi, efektivitas dan produktivitas organisasi.

Undang-undang Republik Indonesia Nomor 20 tahun 2003 tentang Sistem Pendidikan Nasional Bab XI Pasal 40 ayat 2b mengemukakan bahwa pendidik dan tenaga kependidikan berkewajiban mempunyai komitmen secara profesional untuk meningkatkan mutu pendidikan.

Profesionalisme tenaga pendidik sangat berhubungan erat dengan mutu pendidikan, sebab proses belajar sebagai inti dari pendidikan akan sangat tergantung pada tenaga pendidik yang professional dan kualitas hasil belajar merupakan ujung tombak kualitas pendidikan. Dengan anggapan semacam itu, maka keberadaan tenaga pendidik atau guru yang profesional semakin penting, dan peranan siswa dalam belajar merupakan tumpuan upaya peningkatan kualitas pendidikan sesuai standar nasional pendidikan. Pasal 35 UU Nomor 20 Tahun 2003 tentang Sistem Pendidikan Nasional mengamanatkan agar Pendidikan memiliki Standar Nasional Pendidikan (SNP), sebagai acuan pengembangan dan pengendalian pendidikan. Pada Peraturan Pemerintah Nomor 19 Tahun 2005 Bab II Pasal 2 menyebutkan standar nasional pendidikan mencakup standar isi, proses, kompetensi lulusan, tenaga kependidikan, sarana prasarana, pengelolaan, pembiayaan, dan penilaian pendidikan.

Guru merupakan faktor kunci keberhasilan dalam upaya meningkatkan dan memelihara kualitas pendidikan. Sebaik apapun program yang dibuat kalau kualitas gurunya tidak mendapat perhatian yang cukup, maka akhirnya hanya menjadi rutinitas, sedangkan kualitas tidak akan pernah tercapai. Kalau kualitas Sumber Daya Manusia tidak mendapat perhatian yang serius, maka bangsa Indonesia akan ketinggalan oleh bangsa-bangsa lain yang sudah menyadari akan pentingnya kualitas Sumber Daya Manusia. Dalam PP No. 38 Tahun 1992 tentang Tenaga Kependidikan, dijelaskan bahwa, tenaga kependidikan merupakan unsur terpenting dalam sistem pendidikan nasional yang diadakan dan dikembangkan untuk menyelenggarakan pengajaran, pembimbingan dan pelatihan bagi para pendidik. Diantara para tenaga kependidikan ini para guru merupakan unsur utama. Baik tidaknya suatu sekolah atau sebuah kurikulum sangat tergantung dari mutu tenaga pendidiknya, sehingga guru dituntut untuk memenuhi syaratsyarat kemampuan tertentu. Untuk itu maka guru harus senantiasa dikembangkan kemampuannya supaya mutu pembelajaran dapat dipertahankan dan ditingkatkan.

Dalam kondisi demikian, maka jelas pembinaan guru merupakan satu bagian krusial yang perlu mendapat perhatian dalam pengembangan mutu pelayanan pendidikan salah satunya dengan diberikannya pendidikan dan pelatihan. Usman (1998, p.2) Menyatakan bahwa pelatihan adalah tanggung jawab bersama antar penyelenggara, peserta, dan lembaga mengirimkan seseorang (tempat bekerja) sebagai peserta pelatihan.

Pengertian pelatihan merupakan seluruh proses mengajarkan pengetahuan dan keahlian tertentu, sikap semakin te- 
rampil dan mampu melaksanakan tanggung jawabnya dengan baik sesuai dengan standar. Biasanya pelatihan merujuk pada pengembangan keterampilan bekerja (vocational) yang dapat digunakan dengan segera. Di sisi lain, pengembangan memiliki ruang lingkup yang lebih luas. Dapat berupa upaya meningkatkan pengetahuan yang mungkin digunakan segera atau sering untuk kepentingan di masa depan. Pengembangan sering dikategorikan secara eksplisit dalam pengembangan manajemen, organisasi, dan pengembangan individu karyawan. Penekanan lebih pokok adalah pada pengembangan manajemen, tidak pada pekerjaan kini dan mendatang, tetapi lebih pada pemenuhan kebutuhan jangka panjang (Mangkuprawira (2011, p.134).

Tujuan pelatihan Simamora (Sulistiyani \& Rosidah, 2009, pp.220-221) menyebutkan tujuan pelatihan dan pengembangan meliputi: (1) memperbaiki kinerja, memutakhirkan keahlian para karyawan sejalan dengan kemajuan teknologi, (2) mengurangi waktu belajar bagi karyawan baru supaya menjadi kompeten, (3) membantu memecahkan persoalan operasional, (4) mempersiapkan kayawan untuk promosi, dan (5) memenuhi kebutuhan-kebutuhan pertumbuhan pribadi. Tujuan penyelenggaraan pelatihan dan pengembangan menentukan efektifitas dan efisiensi organisasi.

Hal tersebut lantaran guru merupakan penentu keberhasilan pendidikan, sehingga upaya meningkatkan mutu pendidikan harus dimulai dari aspek "guru" dan tenaga kependidikan lainnya yang menyangkut kualitas keprofesionalannya maupun kesejahteraan dalam satu manajemen pendidikan yang professional. Data Balitbang Depdiknas menunjukkan, dari 1.054.859 guru SD negeri ternyata hanya $42,4 \%$ yang layak mengajar. Berarti, sebagian besar $(57,6$ persennya) tidak layak mengajar. http://ilmiahilmu.w.com/2012/06/18/pembinaankemampuanprofesional-guru.

Secara aplikatif, diperlukan peningkatan profesionalisme guru karena guru merupakan pelaksana lapangan yang menjadi ujung tombak. Berbagai upaya pemberdayaan dapat dilakukan di antaranya dengan pembinaan profesionalisme guru melalui supervisi pengajaran, Diklat, Bimtek, work shop.

Namun demikian pada kenyataannya untuk peringkat hasil Ujian Nasional pada tahun ajaran 2011/2012 dan 2012/ 2013 di Kabupaten Sleman masih dikategorikan rendah yaitu peringkat ke empat se Daerah Istimewa Yogyakarta. Apa yang menjadi penyebab dari kondisi seperti itu. Untuk itu Dinas Pendidikan, Pemuda, dan Olahraga Kabupaten Sleman selalu berupaya untuk memperbaiki kondisi tersebut dengan mengadakan kegiatan pelatihan guru di berbagai bidang.

Pelatihan Penyusunan Bahan Ajar Berbasis IT dengan aplikasi Lectora merupakan salah satu strategi untuk peningkatan mutu pendidikan. Karena kondisi di lapangan dilihat dari segi manajeman gugus, manajemen sekolah, administrasi sekolah, pembelajaran di sekolah, dan pelaksanaannya belum sesuai dengan ketentuan yang berlaku, maka Dinas Pendidikan, Pemuda, dan Olahraga Kabupaten Sleman tahun 2013 telah melaksanakan kegiatan pelatihan guru. (Dokumen Laporan Panitia Kegiatan Pembinaan Guru tahun 2012).

Adanya perubahan dalam teknologi khususnya, Information Technology (IT) atau Teknologi informasi (TI), membawa paradigma baru pada learning material dan learning method. Produk IT dewasa ini telah memberikan alternatif berupa bahan belajar yang dapat digunakan dan diakses oleh peserta didik yang tidak dalam bentuk kertas, tetapi berbentuk CD, DVD, flashdisk, dan lain-lain. Inti bahan ajar tersebut berupa program/software yang dapat dimanfaatkan bukan hanya sekedar untuk mengambil data, membaca, mengunduh, bahkan sampai berinteraksi antara program peserta didik dengan guru dengan memanfaatkan komputer sebagai perangkat utama. Perkembangan mutakhir menunjukkan bahwa pembelajaran berbasis komputer semakin mengarah pada pemanfaatan tekno- 
logi World Wide Web (WWW) dengan istilah-istilah CAI (Computer aided Instruction), CBL (Computer Based Learning), CBT (Computer Based Training), telah mengubah penampilan dan distribusi bahan ajar secara revolusioner, (Wibawanto, Jurnal. Bahan ajar berbasis komputer. XVIII, 1, 191).

Mayer (2005, p.3) menyatakan "Multimedia intruction (or a multimedia learning environment) involves presenting words and pictures that are intended to promote learning". Pernyataan tersebut kurang lebih dapat diterjemahkan multimedia melibatkan penyajian kata-kata dan gambar yang dimaksudkan untuk meningkatkan pembelajaran. Adapun fungsi media dinyatakan oleh ahli multimedia. Darmawan (2012, pp.3940) menyebutkan ada tiga fungsi media (termasuk internet) di dalam kegiatan pembelajaran, yaitu sebagai suplemen, komplemen, dan substitusi, berikut penjelasannya.

Sesuai dengan Peraturan Menteri Pendidikan nasional Nomor 16 Tahun 2007 tentang Standar Kualifikasi Akademik dan Kompetensi Guru menyebutkan bahwa guru harus memiliki empat kompetensi yaitu: kompetensi pedagogik, kompetensi akademik, kompetensi sosial, dan kompetensi kepribadian. Guru yang kompeten sangat dibutuhkan dalam upaya peningkatan mutu pendidikkan karena guru yang kompeten akan mampu melaksanakan tugasnya dengan baik, dapat mengaplikasikan teknologi dalam kegiatan mengajarnya. Anderson (Sopiatin, 2010, pp.65-66) menyebutkan bahwa "guru yang efektif mempunyai karakteristik mempunyai kemampuan, pengetahuan yang luas, dan kualitas personal yang baik". Di samping empat kompetensi tersebut sesuai perkembangan jaman, guru juga dituntut agar bisa menggunakan Teknologi Informasi (TI) yang salah satunya digunakan untuk menyusun bahan ajar. Kenyataan di lapangan sampai saat ini masih ada sebagian guru yang belum memiliki kompetensi tersebut, sehingga dalam melaksanakan pembelajaran hanya menggunakan metode yang sudah tidak sesuai lagi, diantaranya tidak menggunakan media pembelajaran berbasis TI, bahkan di sekolah-sekolah di wilayah Ka- bupaten Sleman masih sangat banyak guru menggunakan bahan ajar buatan orang lain ataupun bikinan pabrik pada pembelajaran yang mereka lakukan. Padahal mereka sadar bahwa bahan ajar yang mereka gunakan itu seringkali tidak sesuai dengan konteks dan situasi sosial budaya peserta didik. Hal ini merupakan merupakan sebuah fenomena yang sungguh memprihatinkan.

Sementara berdasarkan Undang-undang Nomor 14 tahun 2005 tentang Guru dan Dosen, guru harus professional. Pada pasal 8 disebutkan bahwa "Guru wajib memiliki kualifikasi akademik, kompetesi, sertifikasi pendidik, sehat jamani dan rohani, serta memiliki kemampuan untuk mewujudkan tujuan pendidikan nasional. Kompetensi guru sebagaimana dimaksud dalam undang-undang tersebut meliputi kompetensi pedagogis, kompetensi kepribadian, kompetensi sosial, dan kompetensi professional yang diperoleh melalui pendidikan profesi.

Kompetensi inti yang wajib dimiliki oleh seorang guru atau dosen di antaranya adalah "mengembangkan kurikulum yang terkait dengan bidang pengembangan yang diampu dan menyelenggarakan kegiatan pengembangan yang mendidik". Salah satunya dari kompetensi tersebut adalah mengembangkan materi pembelajaran yang diampu secara kreatif, dan memanfaatkan teknologi informasi dan komunikasi untuk berkomunikasi dan mengembangkan diri. Guru atau dosen dituntut untuk mampu menyusun bahan ajar yang inovatif (bisa berujud bahan ajar cetak, model/maket, bahan ajar audio, bahan ajar audiovisual, ataupun bahan ajar interaktif) sesuai dengan perkembangan kebutuhan peserta didik, maupun perkembangan teknologi informasi.

Oleh karena itu dalam rangka meningkatkan profesionalitas guru, karena guru sebagai agen pembelajaran dituntut selalu mengikuti perkembangan ilmu pengetahuan dan teknologi, dan tidak ketinggalan pengetahuan di bidang teknologi informasi, maka Dinas Pendidikan, Pemuda, dan olahraga Kabupaten Sleman melaksanakan kegiatan pelatihan penyusunan 
bahan ajar berbasis lectora. Deskripsi Lectora yang dirangkum dalam Panduan Laporan Kegiatan Penyusunan Bahan Ajar berbasis Teknologi Informasi adalah perangkat lunak Authoring Tool untuk pengembangan e-learning yang dikembangkan oleh Trivantis Corporation. Lectora bisa digunakan untuk membuat website, konten e-learning interaktif, dan presentasi. Perangkat Authoring Tool ini juga memungkinkan untuk mengkonversi presentasi Microsoft Power Point ke konten e-learning. Konten yang dikembangkan dengan perangkat lunak lectora dapat dipublikasikan ke berbagai output, seperti HTML, Single file executable, CD-ROM, maupun standar e-learning seperti SCROM dan AICC.

Dalam pelaksanaan diklat kadang dari peserta yang telah direkrut ada acara yang berbenturan, sehingga pihak dinas kesulitan mencari pengganti. Lain dari pada itu terkadang materi yang diberikan kepada peserta kurang sesuai dengan kebutuhan peserta pelatihan.

Pada tahun 2013 dilakukan pembinaan profesionalisme guru di Dinas Dikpora Kabupaten Sleman melalui berbagai kegiatan diantaranya: workshop, diklat penyusunan Karya Tulis Ilmiah (KTI), Pembuatan Media Pembelajaran, diklat penyusunan bahan ajar berbasis TI (Teknologi Informasi), dan lebih khusus lagi pelatihan penyusunan bahan ajar berbasis lectora. Pembinaan profesionalisme guru disesuaikan dengan standar yang telah ditentukan. Adapun tujuan diadakan pelatihan penyusunan bahan ajar berbasis lectora adalah "Agar guru dapat menyusun bahan ajar sebagai media pembelajaran sesuai mata pelajaran yang diampu dan terpenuhinya standar kompetensi guru terutama kompetensi pedagogik". Untuk mengetahui keberhasilan pelaksanaan pelatihan penyusunan bahan ajar berbasis lectora yang bertujuan peningkatan profesional guru dalam hal ini khususnya terpenuhinya kompetensi pedagogik, maka perlu dilakukan evaluasi untuk melihat bagaimana penerapan ilmu yang sudah didapat setelah mengikuti pelatihan melalui diklat.
Usman (1998, p.85), mengemukakan evaluasi adalah proses pengambilan keputusan dengan menggunakan informasi yang diperoleh melalui pengukuran hasil belajar baik mengunakan instrumen tes maupun nontes. Jadi maksud evaluasi adalah untuk memberi nilai tentang mutu sesuatu. Sedangkan menurut Tyler (Arikunto dan Jabar, 2010, p.5), evaluasi program adalah proses untuk mengetahui apakah tujuan pendidikan sudah dapat direalisasikan. Dapat dikatakan kegiatan yang bertujuan untuk mengetahui sejauhmana program dapat terlaksana. Dengan demikian dapat disimpulkan bahwa evaluasi merupakan proses penentuan hasil yang dicapai oleh beberapa kegiatan yang direncanakan untuk mendukung tercapainya tujuan.

Noe (2005, p.172) mengemukakan alasan untuk melakukan evaluasi program pelatihan yaitu untuk: (1) mengidentifikasi kelebihan dan kekurangan program pelatihan; (2) menilai dari isi, organisasi maupun admistrasi pelatihan; (3) mengidentifikasi bagian yang paling bermanfaat maupun kurang bermanfaat bagi peserta pelatihan; (4) untuk membantu memasarkan program pelatihan dengan kumpulan informasi dari peserta pelatihan yang merekomendasikan program pelatihan kepada orang lain, alasan mengikuti pelatihan dan tingkat kepuasan terhadap program pelatihan; dan (5) untuk menentukan keuntungan finansial dan harga dari pelaksanaan program.

Menurut Scriven (Kaufman \& Thomas, 1980, p.131) disebutkan: evaluasi mempunyai dua manfaat/fungsi formatif dan sumatif. Jika evaluasi dilakukan pada saat kegiatan sedang berjalan, dimaksudkan untuk perbaikan dan pengembangan, maka disebut evaluasi formatif. Sedang bila dilakukan di akhir kegiatan dan dimaksudkan untuk membantu pertanggungjawaban, keterangan, seleksi atau lanjutan disebut evalusi sumatif. Fungsi evaluasi dibedakan menjadi empat yaitu ntuk: (1) efektivitas, (2) efisiensi, (3) utilitas, dan (4) akuntabilitas. 
Alasan utama untuk melakukan evaluasi diklat adalah untuk mengetahui keefektifan program pelatihan dan untuk melihat bagian dari program pelatihan yang perlu ditingkatkan. Dikarenakan Lembaga BTKP dan Dinas Dikpora Kabupaten Sleman belum pernah melaksanakan evaluasi pelatihan penyusunan bahan ajar dengan program lectora. Evaluasi tidak hanya untuk memperkuat sikap kerja dalam pekerjaan, tetapi juga untuk memperlihatkan hasil dari program pelatihan. Evaluasi program pelatihan diperlukan untuk mengetahui pencapaian tujuan pelatihan, kemajuan yang diperoleh peserta pelatihan apakah kompetensi pedagogik guru dapat terpenuhi. Berdasarkan permasalahan di atas, maka perlu dilakukan evaluasi program pelatihan yaitu untuk mengetahui seberapa tinggi keefektifan pelatihan penyusunan bahan ajar berbasis lectora tersebut dalam rangka terpenuhinya kompetensi pedagogik guru di Dinas Pendidikan, Pemuda, dan Olahraga (Dinas Dikpora) Kabupaten Sleman. Dapat dikatakan evaluasi dilakukan untuk mengetahui penyelenggaraan pelatihan penyusunan bahan ajar berbasis lectora, kemampuan fasilitator pelatihan, kualitas hasil belajar peserta dan perilaku kerja tamatan pelatihan khususnya kompetensi pedagogik. Hal inilah yang mendorong untuk melaksanakan penelitian yang berjudul "Keefektifan Pelatihan Penyusunan Bahan Ajar Berbasis Lectora di Dinas Pendidikan, Pemuda, dan Olahraga Kabupaten Sleman"

\section{Metode}

Jenis Penelitian

Penelitian ini merupakan penelitian evaluasi tentang keefektifan pelatihan guru yang diselenggarakan oleh Dinas Dikpora Kabupaten Sleman pada bagian Subdin Bidang Pelatihan Tenaga Pendidik dan Kependidikan khususnya TK/SD, SMP, SMA/SMK. Di dalam penelitian ini pendekatan yang digunakan adalah pendekatan kuantitatif yang dikembangkan berdasarkan konsep Kirpatrik dengan empat tingkatan yaitu: (1) evaluasi tingkat reaksi (reaction); (2) evaluasi tingkat belajar (learning); (3) evaluasi tingat perilaku (behavior), dan (4) evaluasi tingkat dampak.

\section{Tempat dan Waktu Penelitian}

Penelitian ini dilakukan di Dinas Dikpora Kabupaten Sleman, bagian Sub Dinas Bidang Pembinaan Tenaga Pendidik dan Kependidikan TK/SD, SMP, SMA/ SMK, yang kegiatannya dilaksanakan di Hotel Disaster Oasis Training Center. Waktu penelitian dimulai tanggal 27 September 2013 sampai dengan tanggal 3 Desember 2013.

\section{Subjek dan Objek Penelitian}

Subjek penelitian ini mengambil seluruh peserta pelatihan guru yaitu guru Tk, SD, SMP, SMA, dan SMK yang mengikuti pelatihan penyusuan bahan ajar berbasis lectora dari masing-masing sekolah di Wilayah Kabupaten Sleman. Masing-masing tingkat jenjang pendidikan diwakili oleh sorang guru, dan dijadikan subjek penelitian. Sedangkan obyek penelitiannya adalah kemampuan peserta dalam menyusun bahan ajar berbasis lectora dalam bentuk compact disc yang berisi contoh seperangkat bahan ajar berbasis lectora, yang dikumpulkan di Dinas Dikpora seminggu setelah mengikuti pelatihan guru.

Adapun jumlah populasi penelitian pelatihan penyusunan bahan ajar berbasis lectora dapat dilihat pada Tabel 1.

Tabel 1. Jumlah Populasi

\begin{tabular}{llccc}
\hline No & $\begin{array}{c}\text { Jenjang } \\
\text { Pendidikan }\end{array}$ & $\begin{array}{c}\text { Jumlah } \\
\text { Guru }\end{array}$ & $\begin{array}{c}\text { Jumlah } \\
\text { Kepala } \\
\text { Sekolah }\end{array}$ & Evaluator \\
\hline 1 & TK & 20 & 20 & \\
2 & SD & 30 & 30 & \\
3 & SMP & 26 & 26 & \\
4 & SMA & 11 & 11 & \\
5 & SMK & 13 & 13 & \\
6 & Ahli Media & - & - & 1 \\
& JUMLAH & 100 & 100 & 1 \\
\hline
\end{tabular}

Berdasarkan tabel 1 yang menjadi subjek penelitian adalah Guru TK, SD, SMP, SMA, dan SMK di wilayah Kabu- 
paten Sleman sebagai peserta pelatihan berjumlah 100 orang guru dan 100 orang kepala sekolah. Dari 100 orang peserta pelatihan dan 100 orang kepala sekolah masing-masing diambil 30 orang untuk uji coba instrumen dan sisanya 70 orang peserta pelatihan dan 70 orang kepala sekolah. Namun dikarenakan ada salah satu peserta yang telah pindah tempat kerja, dari SD Bokong Kecamatan Seyegan pindah bekerja ke Kabupaten Kulonprogo maka data yang dapat diambil hanya 69 peserta pelatihan, 69 kepala sekolah, dan satu evaluator untuk penelitian dengan tabulasi disajikan pada Tabel 2.

Tabel 2. Sebaran Subjek Penelitian

\begin{tabular}{llccc}
\hline No & $\begin{array}{c}\text { Jenjang } \\
\text { Pendidikan }\end{array}$ & $\begin{array}{c}\text { Jumlah } \\
\text { Guru }\end{array}$ & $\begin{array}{c}\text { Jumlah } \\
\text { Kepala } \\
\text { Sekolah }\end{array}$ & Evaluator \\
\hline 1 & TK & 15 & 15 & \\
2 & SD & 23 & 23 & \\
3 & SMP & 16 & 16 & \\
4 & SMA & 7 & 7 & \\
5 & SMK & 8 & 8 & \\
6 & Ahli & - & - & 1 \\
& Media & & & \\
& JUMLAH & 69 & 69 & 1 \\
\hline
\end{tabular}

Teknik Pengumpulan Data dan Teknik Analisis Data

Teknik pengumpulan data yang digunakan pada penelitian ini adalah angket, dan dokumentasi. Instrumen penelitian ini menggunakan angket, yang dibuat secara rating scale (Sugiyono, 2011, p.141). Angket dibuat dalam empat komponen, yaitu: (1) komponen penyelenggaraan pelatihan, (2) komponen kemampuan fasilitator, (3) komponen kualitas hasil belajar yang terdiri dari aspek pembelajaran dan aspek isi, dan (4) komponen kompetensi pedagogik. Komponen satu dan dua degan responden peserta pelatihan, komponen tiga dengan responden evaluator, dan komponen empat dengan responden kepala sekolah. Setiap item pernyataan dalam angket disediakan empat kriteria yaitu: (1) jika kurang baik/kurang efektif, (2) jika cukup baik/ cukup efektif, (3) jika baik/efektif, dan (4) jika sangat baik/sangat efektif. Dilakukan uji validitas dan reliabilitas instrument penelitian.

Data yang terkumpul kemudian dianalisis dengan statistik deskriptif dalam bentuk skor / nilai rerata (M) dan simpang baku (SD), dan kategorisasi. Analisis data yang dilakukan dengan tahapan: (a) penskoran jawaban responden, (b) penjumlahan skor total masing masing komponen, (c) pengelompokan skor yang didapat, dan (d) mengolah skor yang didapat oleh responden berdasarkan keterkaitan antar variabel.

\section{Hasil Penelitian dan Pembahasan}

Pada penelitian ini, untuk mendapatkan data penelitian menggunakan angket dengan tiga cara yaitu angket yang pertama, disebarkan kepada peserta pelatihan pada hari terakhir pelatihan untuk mendapatkan data tanggapan peserta pelatihan terhadap komponen penyelenggaraan pelatihan dan tanggapan peserta terhadap kemampuan fasilitator. Jumlah responden dalam penelitian ini adalah 69 orang peserta dengan rincian 15 peserta dari tingkat jenjang pendidikan TK, 23 peserta dari SD, 16 peserta dari SMP, 7 peserta dari SMA, dan 8 peserta dari SMK. Angket kedua, untuk mendapatkan data hasil prestasi belajar peserta yang berbentuk compact disc yang oleh peserta dikumpulkan di Dinas Dikpora Kabupaten Sleman seminggu setelah pelatihan berakhir, dengan cara mengambil hasil penilaian dari evaluator yang telah ditunjuk oleh lembaga Dikpora Kabupaten Sleman, dan angket ketiga untuk mendapatkan data pemenuhan kompetensi pedagogik dengan cara meminta bantuan kepada 69 kepala sekolah yang telah mengirimkan guru sebagai peserta pelatihan untuk mendapatkan informasi terpenuhinya standar kompetensi pedagogik.

Respon Peserta terhadap Penyelenggaraan Pelatihan

Respon peserta terhadap penyelenggaraan pelatihan merupakan penilaian pe- 
serta terhadap penyelenggaraan pelatihan yang dilaksanakan di Dinas Dikpora Kabupaten Sleman. Peserta pelatihan memberikan respon terhadap indikator pelaksanaan pelatihan sesuai dengan kriteria yang telah ditetapkan kuesioner respon penyelenggaraan pelatihan adalah struktur kegiatan, pelayanan kesekretariatan, ruang pelatihan, materi pelatihan, dan konsumsi.

Tabel 3. Keefektifan Struktur Kegiatan

\begin{tabular}{ccccc}
\hline No & Skor & Kriteria & Jumlah & Persentase \\
\hline 1 & $\leq 5,25$ & $\begin{array}{c}\text { Kurang } \\
\text { efektif }\end{array}$ & 5 & 7,30 \\
2 & $5,26-7,50$ & $\begin{array}{c}\text { Cukup } \\
\text { efektif }\end{array}$ & 5 & 7,20 \\
3 & $7,51-9,75$ & $\begin{array}{c}\text { Efektif } \\
4\end{array}$ & 6 & 8,70 \\
& $>9,75$ & $\begin{array}{l}\text { Sangat } \\
\text { efektif }\end{array}$ & 53 & 76,80 \\
\hline
\end{tabular}

Berdasarkan tabel 3 dapat diketahui bahwa terdapat 5 responden $(7,30 \%)$ yang berada pada ketegori kurang efektif, 5 responden $(7,20 \%)$ berada pada kategori cukup efektif dan 6 responden $(8,70 \%)$ berada pada kategori efektif, dan 53 responden $(76,80 \%)$ berada pada kategori sangat efektif. Sedangkan berdasarkan dari nilai rata-rata (mean) sebesar 9,53 adalah berada pada ketegori efektif yang artinya struktur kegiatan pelatihan efektif untuk guru-guru peserta pelatihan. Sedangkan keefektifan pelayanan kesekretariatan dapat disajikan pada tabel 4 berikut ini:

Tabel 4. Keefektifan Pelayanan Kesekretariatan

\begin{tabular}{ccccc}
\hline No & Skor & Kriteria & Jumlah & Persentase \\
\hline 1 & $\leq 7,00$ & $\begin{array}{c}\text { Kurang } \\
\text { efektif }\end{array}$ & 11 & 16,10 \\
2 & $7,01-10,00$ & $\begin{array}{c}\text { Cukup } \\
\text { efektif }\end{array}$ & 5 & 7,20 \\
3 & $10,01-13,00$ & Efektif & 16 & 23,10 \\
4 & $>13,00$ & $\begin{array}{l}\text { Sangat } \\
\text { efektif }\end{array}$ & 37 & 53,60 \\
& Jumlah & & 69 & 100 \\
\hline
\end{tabular}

Berdasarkan tabel 4 dapat diketahui bahwa terdapat 11 responden $(16,10 \%)$ yang berada pada ketegori kurang efektif, 5 responden $(7,20 \%)$ berada pada kategori cukup efektif, 16 responden $(23,10 \%)$ berada pada berada pada kategori efektif, 37 responden $(53,60 \%)$ pada kategori sangat efektif. Sedangkan berdasarkan dari nilai rata-rata (mean) sebesar 12,69 adalah berada pada ketegori efektif yang artinya pelayanan kesekretariatan pelatihan efektif untuk guru-guru peserta pelatihan. Untuk keefektifan ruang pelatihan akan disajikan pada tabel 5 berikut ini.

Tabel 5. Keefektifan Ruang Pelatihan

\begin{tabular}{ccccc}
\hline No & Skor & Kriteria & Jumlah & Persentase \\
\hline 1 & $\leq 7,00$ & $\begin{array}{c}\text { Kurang } \\
\text { efektif }\end{array}$ & 15 & 21,80 \\
2 & $7,01-10,00$ & $\begin{array}{c}\text { Cukup } \\
\text { efektif }\end{array}$ & 0 & 0,00 \\
3 & $10,01-13,00$ & $\begin{array}{c}\text { Efektif } \\
\text { Sangat } \\
4\end{array}$ & 17 & 24,60 \\
& $>13,00$ & $\begin{array}{l}\text { efektif } \\
\text { Jumlah }\end{array}$ & 69 & 100 \\
\hline
\end{tabular}

Berdasarkan tabel 5 dapat diketahui bahwa terdapat 15 responden (21,80\%) yang berada pada ketegori kurang efektif, 17 responden $(24,60 \%)$ berada pada kategori efektif, 37 responden $(53,6 \%)$ berada pada kategori sangat efektif, Sedangkan ber-dasarkan dari nilai rata-rata (mean) sebesar 12,60 adalah berada pada ketegori efektif yang artinya ruang pelatihan yang disediakan efektif untuk guru-guru peserta pelatihan. Selain keefektifan aspek struktur kegiatan dan aspek pelayanan kesekretariatan, berikut disajikan tabel 6 untuk aspek keefektifan materi pelatihan.

Tabel 6. Keefektifan Materi Pelatihan

\begin{tabular}{|c|c|c|c|c|}
\hline No & Skor & Kriteria & Jumlah & Persentase \\
\hline 1 & $\leq 7,00$ & $\begin{array}{c}\begin{array}{c}\text { Kurang } \\
\text { efektif }\end{array} \\
\text { ef }\end{array}$ & 1 & 1,40 \\
\hline 2 & $7,01-10,00$ & $\begin{array}{l}\text { Cukup } \\
\text { efektif }\end{array}$ & 0 & 0,00 \\
\hline 3 & $10,01-13,00$ & Efektif & 8 & 11,60 \\
\hline \multirow[t]{2}{*}{4} & $>13,00$ & $\begin{array}{l}\text { Sangat } \\
\text { efektif }\end{array}$ & 60 & 87,00 \\
\hline & Jumlah & & 69 & 100 \\
\hline
\end{tabular}


Berdasarkan tabel 6 dapat diketahui bahwa terdapat 1 responden $(1,40 \%)$ yang berada pada ketegori kurang efektif, 8 responden $(11,60 \%)$ berada pada kategori efektif, 60 responden $(87 \%)$ berada pada kategori sangat efektif, Sedangkan berdasarkan dari nilai rata-rata (mean) sebesar 14,34 adalah berada pada ketegori sangat efektif yang artinya materi pelatihan sangat efektif diberikan untuk guru-guru peserta pelatihan. Adapun keefektifan konsumsi yang disajikan selama pelatihan, berikut ditampilkan Tabel 7.

Tabel 7. Keefektifan Konsumsi

\begin{tabular}{|c|c|c|c|c|}
\hline No & Skor & Kriteria & Jumlah & Persentase \\
\hline 1 & $\begin{array}{c}\leq \\
5,25\end{array}$ & $\begin{array}{l}\text { Kurang } \\
\text { efektif }\end{array}$ & 6 & 8,80 \\
\hline 2 & $\begin{array}{c}5,26- \\
7,50\end{array}$ & $\begin{array}{l}\text { Cukup } \\
\text { efektif }\end{array}$ & 5 & 7,20 \\
\hline 3 & $\begin{array}{c}7,51- \\
9,75\end{array}$ & Efektif & 6 & 8,70 \\
\hline 4 & $\begin{array}{c}> \\
9,75\end{array}$ & $\begin{array}{l}\text { Sangat } \\
\text { efektif }\end{array}$ & 52 & 75,30 \\
\hline \multicolumn{3}{|c|}{ Jumlah } & 69 & 100 \\
\hline
\end{tabular}

Berdasarkan tabel 7 dapat diketahui bahwa terdapat 6 responden $(8,80 \%)$ yang berada pada ketegori kurang efektif, 5 responden $(7,20 \%)$ berada pada kategori $\mathrm{cu}$ kup efektif, 6 responden $(8,70 \%)$ berada pada kategori efektif, dan 52 responden $(75,30 \%)$ berada pada kategori sangat efektif. Sedangkan berdasarkan dari nilai ratarata (mean) sebesar 7,36 adalah berada pada ketegori cukup efektif yang artinya konsumsi yang disajikan cukup efektif diberikan untuk guru-guru peserta pelatihan. Untuk kemampuan fasilitator, respon peserta terhadap kemampuan fasilitator disajikan pada tabel 8 berikut ini.

Respon Peserta terhadap Kemampuan Fasilitator

Respon peserta terhadap fasilitator merupakan penilaian peserta terhadap kemampuan fasilitator pelatihan dalam menjelaskan materi pelatihan, penggunaan metode mengajar, pemanfaatan media dan peralatan belajar, menggunakan bahan pengajaran, menjawab pertanyaan yang diajukan peserta, menjalin komunikasi dengan peserta, serta kemampuan dalam mengakhiri pelatihan. Berikut tabulasi data respon peserta terhadap fasilitator pelatihan pada masing-masing indikator penelitian.

Tabel 8. Keefektifan Kemampuan Menjelaskan

\begin{tabular}{|c|c|c|c|c|}
\hline No & Skor & Kriteria & Jumlah & Persentase \\
\hline 1 & $\leq 5,25$ & $\begin{array}{l}\text { Kurang } \\
\text { efektif }\end{array}$ & 0 & 0,00 \\
\hline 2 & $5,26-7,50$ & $\begin{array}{l}\text { Cukup } \\
\text { efektif }\end{array}$ & 5 & 7,20 \\
\hline 3 & $7,51-9,75$ & Efektif & 0 & 0,00 \\
\hline \multirow[t]{2}{*}{4} & $>9,75$ & $\begin{array}{l}\text { Sangat } \\
\text { efektif }\end{array}$ & 64 & 92,80 \\
\hline & Jumlah & & 69 & 100 \\
\hline
\end{tabular}

Berdasarkan tabel 8 dapat diketahui bahwa terdapat 5 responden $(7,20 \%)$ yang berada pada ketegori cukup efektif dan 64 responden $(92,20 \%)$ berada pada kategori sangat efektif, Sedangkan berdasarkan dari nilai rata-rata (mean) sebesar 9,92 adalah berada pada ketegori sangat efektif yang artinya kamampuan fasilitator pelatihan dalam menjelaskan materi sangat efektif. Kemampuan menggunakan metode mengajar disajikan pada Tabel 9.

Tabel 9. Keefektifan Kemampuan Menggunakan Metode Mengajar

\begin{tabular}{|c|c|c|c|c|}
\hline No & Skor & Kriteria & Jumlah & Persentase \\
\hline 1 & $\leq 5,25$ & $\begin{array}{c}\text { Kurang } \\
\text { efektif }\end{array}$ & 2 & 3,00 \\
\hline 2 & $5,26-7,50$ & $\begin{array}{l}\text { Cukup } \\
\text { efektif }\end{array}$ & 5 & 7,20 \\
\hline 3 & $7,51-9,75$ & Efektif & 0 & 0,00 \\
\hline 4 & $>9,75$ & $\begin{array}{l}\text { Sangat } \\
\text { efektif }\end{array}$ & 62 & 89,80 \\
\hline \multicolumn{3}{|c|}{ Jumlah } & 69 & 100 \\
\hline
\end{tabular}

Berdasarkan Tabel 9 dapat diketahui bahwa terdapat 2 responden $(3,00 \%)$ yang berada pada ketegori kurang efektif, 5 responden $(7,20 \%)$ berada pada kategori $\mathrm{cu}$ kup efektif, 62 responden $(89,80 \%)$ berada pada kategori sangat efektif. Sedangkan 
berdasarkan dari nilai rata-rata (mean) sebesar 10,36 adalah berada pada ketegori sangat efektif yang artinya penggunaan metode mengajar sangat efektif untuk guru-guru peserta pelatihan. Untuk keefektifan menggunakan media pembelajaran disajikan Tabel 10.

Tabel 10. Keefektifan Menggunakan Media Pembelajaran

\begin{tabular}{ccccc}
\hline No & Skor & Kriteria & Jumlah & Persentase \\
\hline 1 & $\leq 7,00$ & $\begin{array}{c}\text { Kurang } \\
\text { efektif }\end{array}$ & 0 & 0,00 \\
2 & $7,01-10,00$ & $\begin{array}{c}\text { Cukup } \\
\text { efektif }\end{array}$ & 0 & 0,00 \\
3 & $10,01-13,00$ & $\begin{array}{c}\text { Efektif } \\
4\end{array}$ & 16 & 23,20 \\
& Jumlah & & 69 & 100 \\
\hline
\end{tabular}

Berdasarkan Tabel 10 dapat diketahui bahwa terdapat 16 responden $(23,20 \%)$ yang berada pada ketegori efektif, dan 53 responden $(76,80 \%)$ berada pada kategori sangat efektif. Sedangkan berdasarkan dari nilai rata-rata (mean) sebesar 14,39 adalah berada pada ketegori sangat efektif yang artinya fasilitator dalam menggunakan media pembelajaran sangat efektif untuk guru-guru peserta pelatihan. Berikut disajikan keefektifan kemampuan menjawab pertanyaan pada Tabel 11.

Tabel 11. Keefektifan Kemampuan Menjawab Pertanyaan

\begin{tabular}{ccccc}
\hline No & Skor & Kriteria & Jumlah & Persentase \\
\hline 1 & $\leq 3,50$ & $\begin{array}{c}\text { Kurang } \\
\text { efektif }\end{array}$ & 3 & 4,30 \\
2 & $3,51-5,00$ & $\begin{array}{c}\text { Cukup } \\
\text { efektif }\end{array}$ & 0 & 0,00 \\
3 & $5,01-6,50$ & $\begin{array}{c}\text { Efektif } \\
4\end{array}$ & 0 & 0,00 \\
& $>6,50$ & $\begin{array}{c}\text { Sangat } \\
\text { efektif }\end{array}$ & 66 & 95,70 \\
\hline
\end{tabular}

Berdasarkan tabel 11 dapat diketahui bahwa terdapat 3 responden $(4,30 \%)$ yang berada pada ketegori kurang efektif, dan 66 responden $(95,7 \%)$ berada pada kategori sangat efektif. Sedangkan berdasarkan dari nilai rata-rata (mean) sebesar 7,05 adalah berada pada ketegori sangat efektif yang artinya fasilitator dalam menjawab pertanyaan dari peserta pelatihan media pembelajaran sangat efektif untuk guru-guru peserta pelatihan. Sedangkan untuk keefektifan kemampuan fasilitator dalam komunikasi dengan peserta disajikan pada Tabel 12.

Tabel 12. Keefektifan Kemampuan Komunikasi dengan Peserta

\begin{tabular}{|c|c|c|c|c|}
\hline No & Skor & Kriteria & Jumlah & Persentase \\
\hline 1 & $\leq 5,25$ & $\begin{array}{l}\text { Kurang } \\
\text { efektif }\end{array}$ & 4 & 5,80 \\
\hline 2 & $5,26-7,50$ & $\begin{array}{l}\text { Cukup } \\
\text { efektif }\end{array}$ & 0 & 0,00 \\
\hline 3 & $7,51-9,75$ & Efektif & 0 & 0,00 \\
\hline \multirow[t]{2}{*}{4} & $>9,75$ & $\begin{array}{l}\text { Sangat } \\
\text { efektif }\end{array}$ & 65 & 94,20 \\
\hline & Jumlah & & 69 & 100 \\
\hline
\end{tabular}

Berdasarkan tabel 12 dapat diketahui bahwa terdapat 4 responden $(5,80 \%)$ yang berada pada ketegori kurang efektif, dan 65 responden $(94,20 \%)$ berada pada kategori sangat efektif. Sedangkan berdasarkan dari nilai rata-rata (mean) sebesar 10,00 adalah berada pada ketegori sangat efektif yang artinya fasilitator dalam berkomunikasi dengan peserta pelatihan sangat efektif. Untuk kemampuan fasilitator mengakhiri materi pelatihan disajikan pada tabel 13 berikut ini.

Tabel 13. Keefektifan Mengakhiri Materi Pelatihan

\begin{tabular}{|c|c|c|c|c|}
\hline No & Skor & Kriteria & Jumlah & Persentase \\
\hline 1 & $\leq 7,00$ & $\begin{array}{c}\text { Kurang } \\
\text { efektif }\end{array}$ & 3 & 4,30 \\
\hline 2 & $7,01-10,00$ & $\begin{array}{l}\text { Cukup } \\
\text { efektif }\end{array}$ & 6 & 8,70 \\
\hline 3 & $10,01-13,00$ & Efektif & 9 & 13,00 \\
\hline \multirow[t]{2}{*}{4} & $>13,00$ & $\begin{array}{l}\text { Sangat } \\
\text { efektif }\end{array}$ & 51 & 74,00 \\
\hline & Jumlah & & 69 & 100 \\
\hline
\end{tabular}

Berdasarkan tabel 13 dapat diketahui bahwa terdapat 3 responden (4,30\%) yang berada pada ketegori kurang efektif, 6 res- 
ponden $(8,70 \%)$ berada pada kategori cukup efektif, 9 responden $(13,00 \%)$ berada pada kategori efektif, 51 responden $(74,00 \%)$ pada kategori sangat efektif. Sedangkan berdasarkan dari nilai rata-rata (mean) sebesar 13,05 adalah berada pada ketegori sangat efektif yang artinya dalam mengakhiri pelatihan fasilitator sangat efektif.

Berdasarkan hasil tersebut dapat dikatakan bahwa peserta mempunyai persepsi yang sangat baik terhadap perilaku fasilitator dalam menjelaskan materi pelatihan, menggunakan metode mengajar, menggunakan media belajar, menjawab pertanyaan yang diajukan peserta pelatihan, komunikasi dengan peserta, dan dalam mengakhiri penyampaian materi pelatihan. Hal ini berarti bahwa kemampuan fasilitator dalam mengajar selama pelatihan sangat efektif.

\section{Komponen Hasil Belajar Peserta Pelatihan}

Komponen hasil belajar peserta yang berbentuk compact disc yang telah dievaluasi oleh evaluator. Untuk mendapatkan data hasil belajar peserta dengan cara meminjam dokumen penilaian yang dilakukan evaluator yang ditunjuk oleh Dinas Dikpora Kabupaten Sleman, berupa hasil penilaian evaluator. Komponen hasil belajar ini terbagi menjadi dua aspek yaitu: aspek pembelajaran yang terdiri dari tiga indikator dan aspek isi terdiri dari empat indikator. Berikut tabulasi data hasil belajar peserta pelatihan yag berupa bahan ajar berasis lectora untuk keefektifan pengembangan kurikulum.

Tabel 14. Keefektifan Pengembangan Kurikulum

\begin{tabular}{ccccc}
\hline No & Skor & Kriteria & Jumlah & Persentase \\
\hline 1 & $\leq 7,00$ & $\begin{array}{c}\text { Kurang } \\
\text { efektif }\end{array}$ & 1 & 1,40 \\
2 & $7,01-10,00$ & $\begin{array}{c}\text { Cukup } \\
\text { efektif }\end{array}$ & 0 & 0,00 \\
3 & $10,01-13,00$ & $\begin{array}{c}\text { Efektif } \\
4\end{array}$ & 0 & 0,00 \\
& $>13,00$ & $\begin{array}{c}\text { Sangat } \\
\text { efektif }\end{array}$ & 68 & 98,60 \\
& Jumlah & & 69 & 100 \\
\hline
\end{tabular}

Berdasarkan tabel 14 dapat diketahui bahwa terdapat 1 responden $(1,40 \%)$ yang berada pada ketegori kurang efektif dan 68 responden $(98,60 \%)$ berada pada sangat efektif. Sedangkan berdasarkan dari nilai rata-rata (mean) sebesar 14,00 adalah berada pada ketegori sangat efektif yang artinya guru-guru setelah mengikuti pelatihan dalam mengembangkan kurikulum sangat efektif. Adapun keefektifan kesesuaian materi dengan indikator disajikan pada Tabel 15.

Tabel 15. Keefektifan Kesesuaian Materi dengan Indikator

\begin{tabular}{ccccc}
\hline No & Skor & Kriteria & Jumlah & $\begin{array}{c}\text { Persentas } \\
\text { e }\end{array}$ \\
\hline 1 & $\leq 7,00$ & $\begin{array}{c}\text { Kurang } \\
\text { efektif }\end{array}$ & 1 & 1,40 \\
2 & $7,01-10,00$ & $\begin{array}{l}\text { Cukup } \\
\text { efektif }\end{array}$ & 0 & 0,00 \\
3 & $10,01-13,00$ & $\begin{array}{c}\text { Efektif } \\
4\end{array}$ & 16 & 23,10 \\
& $>13,00$ & $\begin{array}{l}\text { Sangat } \\
\text { efektif }\end{array}$ & 52 & 75,50 \\
\hline & Jumlah & 69 & 100 \\
\hline
\end{tabular}

Berdasarkan Tabel 15 dapat diketahui bahwa terdapat 1 responden (1,40\%) yang berada pada ketegori kurang efektif, 16 responden $(23,10 \%)$ berada pada efektif, 52 responden berada pada kategori sangat efektif. Sedangkan berdasarkan dari nilai rata-rata (mean) sebesar 13,56 adalah berada pada ketegori sangat efektif yang artinya peserta dalam menyusun bahan ajar kesesuaian antara materi dengan indikator sangat sesuai. Keefektifan kejelasan petunjuk disajikan Tabel 16.

Tabel 16. Keefektifan Kejelasan Petunjuk

\begin{tabular}{ccccc}
\hline No & Skor & Kriteria & Jumlah & Persentase \\
\hline 1 & $\leq 5,25$ & $\begin{array}{c}\text { Kurang } \\
\text { efektif }\end{array}$ & 0 & 0,0 \\
2 & $5,26-7,50$ & $\begin{array}{c}\text { Cukup } \\
\text { efektif }\end{array}$ & 0 & 0,0 \\
3 & $7,51-9,75$ & $\begin{array}{c}\text { Efektif } \\
4\end{array}$ & 0 & 0,0 \\
& Jumlah & Sangat & 69 & 100 \\
efektif & & 69 & 100 \\
\hline
\end{tabular}


Berdasarkan Tabel 16 dapat diketahui bahwa terdapat 69 responden $(100 \%)$ berada pada kategori sangat efektif. Sedangkan berdasarkan dari nilai rata-rata (mean) sebesar 10,89 adalah berada pada ketegori sangat efektif yang artinya para peserta dalam membuat petunjuk penggunaan bahan ajar Lectora sangat efektif. Adapun keefektifan cakupan isi materi disajikan pada Tabel 17.

Tabel 17. Keefektifan Cakupan Isi Materi

\begin{tabular}{ccccc}
\hline No & Skor & Kriteria & Jumlah & Persentase \\
\hline 1 & $\leq 7,00$ & $\begin{array}{c}\text { Kurang } \\
\text { efektif }\end{array}$ & 7 & 10,20 \\
2 & $7,01-10,00$ & $\begin{array}{c}\text { Cukup } \\
\text { efektif }\end{array}$ & 6 & 8,70 \\
3 & $10,01-13,00$ & $\begin{array}{c}\text { Efektif } \\
4\end{array}$ & 0 & 0,00 \\
& Jumlah & & 69 & 100 \\
\hline
\end{tabular}

Berdasarkan tabel 17 dapat diketahui bahwa terdapat 7 responden $(10,20 \%)$ yang berada pada ketegori kurang efektif, 6 responden $(8,70 \%)$ berada pada cukup efektif, dan 56 responden berada pada kategori sangat efektif. Sedangkan berdasarkan dari nilai rata-rata (mean) sebesar 12,86 adalah berada pada ketegori efektif yang artinya cakupan kedalaman isi materi efektif. Untuk keefektifan penggunaan bahasa disajikan pada Tabel 18.

Tabel 18. Keefektifan Penggunaan Bahasa

\begin{tabular}{ccccc}
\hline No & Skor & Kriteria & Jumlah & Persentase \\
\hline 1 & $\leq 5,25$ & $\begin{array}{c}\text { Kurang } \\
\text { efektif }\end{array}$ & 4 & 5,80 \\
2 & $5,26-7,50$ & $\begin{array}{c}\text { Cukup } \\
\text { efektif }\end{array}$ & 0 & 0,00 \\
3 & $7,51-9,75$ & $\begin{array}{c}\text { Efektif } \\
4\end{array}$ & 0 & 0,00 \\
& $>9,75$ & $\begin{array}{l}\text { Sangat } \\
\text { efektif }\end{array}$ & 65 & 94,20 \\
\hline
\end{tabular}

Berdasarkan tabel 18 dapat diketahui bahwa terdapat 4 responden $(5,80 \%)$ yang berada pada ketegori kurang efektif, 65 responden $(94,20 \%)$ berada pada kategori sangat efektif. Sedangkan berdasarkan dari nilai rata-rata (mean) sebesar 11,07 adalah berada pada ketegori sangat efektif yang artinya penggunaan bahasa dalam pembuatan bahan ajar sangat efektif. Sedangkan untuk keefektifan pendiskripsian materi disajikan pada Tabel 19.

Tabel 19. Keefektifan Pendiskripsian Materi

\begin{tabular}{ccccc}
\hline No & Skor & Kriteria & Jumlah & Persentase \\
\hline 1 & $\leq 7,00$ & $\begin{array}{c}\text { Kurang } \\
\text { efektif }\end{array}$ & 3 & 4,40 \\
2 & $7,01-10,00$ & $\begin{array}{c}\text { Cukup } \\
\text { efektif }\end{array}$ & 0 & 0,00 \\
3 & $10,01-13,00$ & Efektif & 0 & 0,00 \\
4 & $>13,00$ & $\begin{array}{c}\text { Sangat } \\
\text { efektif }\end{array}$ & 66 & 95,60 \\
& Jumlah & & 69 & 100 \\
\hline
\end{tabular}

Berdasarkan Tabel 19 dapat diketahui bahwa terdapat 3 responden $(4,40 \%)$ yang berada pada ketegori kurang efektif, 66 responden $(95,60 \%)$ berada pada kategori sangat efektif. Sedangkan berdasarkan dari nilai rata-rata (mean) sebesar 13,36 adalah berada pada ketegori sangat efektif yang artinya pendiskripsian materi yang dituangkan dalam penyusunan bahan ajar sangat efektif. Untuk keefektifan kesesuaian materi soal disajikan dalam Tabel 20.

Tabel 20. Keefektifan Kesesuaian Materi Soal

\begin{tabular}{ccccc}
\hline No & Skor & Kriteria & Jumlah & Persentase \\
\hline 1 & $\leq 7,00$ & $\begin{array}{c}\text { Kurang } \\
\text { efektif }\end{array}$ & 8 & 11,60 \\
2 & $7,01-10,00$ & $\begin{array}{c}\text { Cukup } \\
\text { efektif }\end{array}$ & 0 & 0,00 \\
3 & $10,01-13,00$ & $\begin{array}{c}\text { Efektif } \\
4\end{array}$ & 0 & 0,00 \\
& Jumlah & & 69 & 100 \\
\hline
\end{tabular}

Berdasarkan Tabel 20 dapat diketahui bahwa terdapat 8 responden $(11,60 \%)$ yang berada pada ketegori kurang efektif, 61 responden $(88,40 \%)$ berada pada kategori sangat efektif. Sedangkan berdasarkan dari nilai rata-rata (mean) sebesar 13,68 adalah berada pada ketegori sangat efektif yang 
artinya kesesuaian antara materi dengan soal yang dibuat sangat efektif.

Berdasarkan hasil tersebut dapat dikatakan bahwa peserta dapat menyusun bahan ajar berbasis lectora yang dinilai dari aspek pembelajaran dan aspek isi sangat efektif, sehingga bahan ajar tersebut dapat digunakan atau diimplementasikan dalam proses belajar mengajar di sekolah masingmasing.

\section{Komponen Kompetensi Pedagogik}

Komponen kompetensi pedagogik terdiri dari tiga subkomponen sebagai standar yang ideal yang harus dikuasai seorang guru meliputi: menguasai karakteristik peserta didi mengembangkan materi pembelajaran; memanfaatkan teknologi informasi dan komunikasi untuk kepentingan pembelajaran. Berikut tabulasi data pemenuhan kompetensi pedagogik guru. Adapun untk keefektifan menguasai karakteristik peserta didik diasajikan pada Tabel 21.

Tabel 21. Keefektifan Menguasai Karakteristik Peserta Didik

\begin{tabular}{ccccc}
\hline No & Skor & Kriteria & Jumlah & Persentase \\
\hline 1 & $\leq 3,50$ & $\begin{array}{l}\text { Kurang } \\
\text { efektif }\end{array}$ & 2 & 3,00 \\
2 & $3,51-5,00$ & $\begin{array}{l}\text { Cukup } \\
\text { efektif }\end{array}$ & 0 & 0,00 \\
3 & $5,01-6,50$ & Efektif & 0 & 0,00 \\
4 & $>6,50$ & $\begin{array}{l}\text { Sangat } \\
\text { efektif }\end{array}$ & 67 & 97,00 \\
& Jumlah & 69 & 100 \\
\hline
\end{tabular}

Berdasarkan Tabel 21 dapat diketahui bahwa terdapat 2 responden $(3,00 \%)$ yang berada pada ketegori kurang efektif dan 67 responden $(97,00 \%)$ berada pada kategori sangat efektif, Sedangkan berdasarkan dari nilai rata-rata (mean) sebesar 7,15 adalah berada pada ketegori sangat efektif yang artinya pemenuhan kompetensi pedagogik yaitu kompetensi menguasai karakteristik peserta didik sangat efektif. Sedangkan keefektifan kompetensi mengembangkan materi disajikan pada tabel 23 berikut ini.
Tabel 22. Keefektifan Mengembangkan Materi

\begin{tabular}{ccccc}
\hline No & Skor & Kriteria & Jumlah & Persentase \\
\hline 1 & $\leq 3,50$ & $\begin{array}{l}\text { Kurang } \\
\text { efektif }\end{array}$ & 2 & 3,00 \\
2 & $3,51-5,00$ & $\begin{array}{l}\text { Cukup } \\
\text { efektif }\end{array}$ & 0 & 0,00 \\
3 & $5,01-6,50$ & $\begin{array}{c}\text { Efektif } \\
\text { Sangat } \\
4\end{array}$ & 0 & 07 \\
& $>6,50$ & $\begin{array}{l}\text { efektif } \\
\text { Jumlah }\end{array}$ & 69 & 100 \\
\hline
\end{tabular}

Berdasarkan Tabel 22 dapat diketahui bahwa terdapat 2 responden $(3,00 \%)$ yang berada pada ketegori kurang efektif dan 67 responden $(97,00 \%)$ berada pada kategori sangat efektif, Sedangkan berdasarkan dari nilai rata-rata (mean) sebesar 7,15 adalah berada pada ketegori sangat efektif yang artinya pemenuhan kompetensi pedagogik yaitu kompetensi mengembangkan materi ajar sangat efektif.

Tabel 23. Keefektifan Pemanfaatan TIK

\begin{tabular}{ccccc}
\hline No & Skor & Kriteria & Jumlah & Persentase \\
\hline 1 & $\leq 5,25$ & $\begin{array}{c}\text { Kurang } \\
\text { efektif }\end{array}$ & 5 & 7,10 \\
2 & $5,26-7,50$ & $\begin{array}{c}\text { Cukup } \\
\text { efektif }\end{array}$ & 9 & 13,00 \\
3 & $7,51-9,75$ & $\begin{array}{c}\text { Efektif } \\
4\end{array}$ & 0 & 0,00 \\
& $>9,75$ & $\begin{array}{l}\text { Sangat } \\
\text { efektif }\end{array}$ & 55 & 79,90 \\
\hline
\end{tabular}

Berdasarkan Tabel 23 dapat diketahui bahwa terdapat 5 responden $(7,10 \%)$ yang berada pada ketegori kurang efektif, 9 responden $(13,00 \%)$ berada pada kategori cukup efektif, 55 responden $(79,90 \%)$ berada pada kategori sangat efektif. Sedangkan berdasarkan dari nilai rata-rata (mean) sebesar 9,95 adalah berada pada ketegori sangat efektif yang artinya pemenuhan kompetensi pedagogik yaitu kompetensi mengembangkan materi ajar sangat efektif.

Berdasarkan hasil tersebut dapat dikatakan bahwa kompetensi menguasai karakteristik peserta didik; mengembangkan materi pembelajaran; dan memanfaatkan 
teknologi informasi dan komunikasi untuk kepentingan pembelajaran sangat baik sehingga standar kompetensi pedagogik guru terpenuhi.

Pembahasan

Dalam melakukan evaluasi pelatihan ini berdasarkan konsep Kirpatrik dengan empat tingkatan yaitu pertama,tingkat reaksi peserta terhadap pelatihan, peserta diklat memberikan reaksi terhadap pelaksanaan diklat dalam bentuk pendapat dan sikap terhadap pelatih, cara menyajikan, media, kegunaan, dan perhatian atas materi diklat. Kedua, tingkat belajar yang menyangkut materi pelatihan yang dilatihkan kepada peserta. Ketiga,evaluasi yang diarahkan pada perubahan perilaku peserta pelatihan, tujuannya adalah apakah hasil diklat yang telah dimiliki peserta dapat diterapkan di tempat tugasnya masingmasing. Keempat adalah dampak pelatihan terhadap lembaga. Tingkatan evaluasi ini untuk mengetahui apakah etos kerja telah menjadi lebih baik, sehingga komponen kompetensi pedagogik terpenuhi. Dengan demikian dapat diketahui seberapa tinggi efektivitas program pelatihan yang dilaksanakan. Diharapkan setelah selesai pelaksanaan pelatihan bisa menjadi bahan masukan bagi penyelenggaraan pelatihan sehingga kekurangan dapat diperbaiki dan dapat lebih meningkatkan program pelatihan berikutnya.

Berdasarkan hasil analisis data yang sudah dipaparkan di atas, maka perlu dilakukan pembahasan terhadap hasil yang didapatkan sehingga bisa diambil kesimpulan dari data penelitian. Berikut ini merupakan pembahasan untuk masing-masing analisis komponen penelitian.

Komponen Respon Peserta terhadap Penyelenggaraan Pelatihan

Pelatihan penyusunan bahan ajar lectora yang perlu dievaluasi adalah bagaimana peserta pelatihan memberikan tanggapan atau reaksi terhadap penyelenggaraan pelatihan. Sesuai pendapat Kirkpatrick bahwa evaluasi pelatihan meliputi empat tingkatan satu diantaranya adalah peserta diklat memberikan reaksi terhadap pelaksanaan diklat dalam bentuk pendapatnya mengenai struktur program pelatihan, pelayanan kesekretariatan, ruang pelatihan, materi pelatihan, dan konsumsi yang disajikan. Secara keseluruhan terdapat 21 responden atau sebesar $31,10 \%$ berada pada kategori kurang efektif $(\leq 31,50)$, 9 responden atau sebesar $13,00 \%$ berada pada kategori cukup efektif $(31,51-45,00), 7$ responden atau sebesar $10,10 \%$ berada pada kategori efektif $(45,01-58,50)$, dan 32 responden atau sebesar $45,80 \%$ berada pada kategori sangat efektif $(>58,50)$. Kesimpulan yang didapatkan dari 69 responden peserta pelatihan penyusunan bahan ajar berbasis lectora yang memberikan tanggapan terhadap penyelenggaraan pelatihan memiliki hasil kecenderungan efektif dengan rata-rata (mean) komulatif 56.55 berada pada kategori efektif $(45,01-58,50)$. Sehingga dapat disimpulkan bahwa penyelenggaraan pelatihan penyusunan bahan ajar berbasis lectora dinyatakan efektif dengan mean 56.55.

\section{Komponen Kemampuan Fasilitator}

Dalam pelatihan penyusunan bahan ajar lectora tak kalah pentingnya juga dievaluasi bagaimana peserta pelatihan memberikan tanggapan terhadap fasilitator. Hal ini senada dengan yang diungkap oleh Kirpatrick (Usman, 1998, p.94) dalam melakukan evaluasi pelatihan meliputi empat tingkatan yaitu salah satu diantara empat adalah memberikan reaksi peserta terhadap pelaksanaan diklat dalam bentuk pendapat peserta terhadap fasilitator, dalam penelitian ini mengevaluasi kemampuan fasilitator tentang cara menjelaskan materi, metode yang digunakan, penggunaan media belajar, menjawab pertanyaan peserta, berkomunikasi dengan peserta, dan kemampuan dalam mengakhiri pemberian materi pelatihan. Dari hasil penelitian komponen kemampuan fasilitator, secara persentase komulatif terdapat 21 responden atau sebesar $30,40 \%$ berada pada kategori kurang efektif $(\leq 33,25), 20$ responden atau sebesar $29,00 \%$ berada pada kategori efektif $(47,51-61,75)$, dan 28 res- 
ponden atau sebesar $40,60 \%$ berada pada kategori sangat efektif (> 61,75). Kesimpulan yang didapatkan dari 69 responden peserta pelatihan penyusunan bahan ajar berbasis Lectora yang memberikan tanggapan terhadap kemampuan fasilitator memiliki hasil kecenderungan sangat efektif dengan rata-rata (mean) komulatif 64,79 berada pada kategori sangat efektif (> 61,75). Sehingga dapat disimpulkan bahwa berdasarkan penilaian peserta terhadap kemampuan fasilitator dalam pelatihan penyusunan bahan ajar berbasis lectora dinyatakan sangat efektif dengan mean 64,79.

\section{Komponen Hasil Belajar Peserta Pelatihan}

Pelatihan membuat atau menyusun ba-han ajar interaktif dengan program lectora diberikan pada guru-guru, dimaksudkan agar guru-guru termotivasi untuk membuat bahan ajar yang kreatif dan inovatif sehingga tercipta pembelajaran menarik dan menyenangkan. Oleh karena itu, untuk mencapai hal demikian maka pelatihan penyusunan bahan ajar interaktif dengan program lectora menjadi penting karena materi-materi yang diberikan dalam pelatihan penyusunan bahan ajar berbasis lectora memberikan kontribusi bagi guru dalam memanfaatkan teknologi informasi. Dalam penelitian dilakukan juga evaluasi hasil belajar peserta pelatihan. Berdasarkan analisis data penelitian, hasil belajar peserta pelatihan dari responden yang berjumlah 69 yang telah di lakukan penilaian oleh seorang evaluator diperoleh hasil bahwa dalam hitungan persen secara komulatif, 25 responden $36,30 \%$ berada pada kategori kurang efektif $(\leq 45,50), 16$ responden atau $23,10 \%$ berada pada kategori cukup efektif $(45,51-65,00), 17$ responden atau $24,70 \%$ berada pada kategori efektif $(65,01-84,50), 11$ responden atau sebesar $15,9 \%$ berada pada kategori sangat efektif $(>84,50)$.

Kesimpulan yang didapatkan dari 69 responden peserta pelatihan penyusunan bahan ajar berbasis Lectora berdasarkan penilaian evaluator memiliki hasil kecenderungan kategori efektif $(65,01-84,50)$ dengan rata-rata (mean) komulatif 75,44.
Sehingga dapat disimpulkan bahwa berdasarkan penilaian evaluator terhadap hasil belajar peserta dalam pelatihan penyusunan bahan ajar berbasis lectora dinyatakan efektif dengan mean 75,44.

\section{Komponen Pemenuhan Kompetensi Pedagogik}

Sebagaimana tercantum dalam Undang-Undang Guru dan Dosen Nomor 14 Tahun 2005 Pasal 8 disebutkan bahwa "Guru wajib memiliki kualifikasi akademik, kompetensi, sertifikasi pendidik, sehat jasmani dan rohani, serta memiliki kemampuan mewujudkan tujuan pendidikan nasional" Kompetensi guru sebagaimana dimaksud dalam undang-undang terebut meliputi kompetensi pedagogis, kompetensi kepribadian, kompetensi sosial yang diperoleh melalui pendidikan profesi.

Dari masing-masing kompetensi tersebut, kompetensi-kompetensi inti yang wajib dimiliki seorang guru atau dosen diantaranya adalah mengembangkan kurikulum yang terkait dengan bidang pengembangan yang diampu dan menyelenggarakan kegiatan pengembangan yang mendidik. Untuk kompetensi pedagogis, serta mengembangkan materi pembelajaran yang diampu secara kreatif dan memanfaatkan teknologi informasi dan komunikasi untuk berkomunikasi dan mengembangkan diri. Dari tuntutan-tuntutan sekaligus kewajiban-kewajiban ini, guru dituntut mampu menyusun bahan ajar yang inovatif yang bisa berujud bahan ajar cetak, model/maket,bahan ajar audio, bahan ajar audiovisual, ataupun bahan ajar interaktif, salah satunya dengan program Lectora sesuai dengan kurikulum, perkembangan kebutuhan peserta didik maupun perkembangan teknologi informasi. Berdasarkan analisis data dan penilaian kepala sekolah dalam hitungan persentase secara keseluruhan pemenuhan komponen pedagogik, dari responden yang berjumlah 69 diperoleh hasil bahwa terdapat 7 responden atau sebesar $10,10 \%$ berada pada kategori kurang efektif $(\leq 12,25), 5$ responden atau sebesar $7,20 \%$ berada pada kategori cukup efektif $(12,26-17,50)$, tidak ada responden yang berada kategori efektif $(17,51-22,75)$ 
atau sebesar $0 \%$ dan 57 responden atau sebesar $82,70 \%$ berada pada kategori sangat efektif $(>22,75)$. Kesimpulan yang didapatkan dari 69 responden peserta pelatihan penyusunan bahan ajar berbasis berdasarkan penilaian kepala sekolah memiliki hasil kecenderungan sangat efektif $(>22,75)$ dengan rata-rata (mean) komulatif 24.10. Sehingga dapat disimpulkan bahwa berdasarkan penilaian evaluator terhadap hasil belajar peserta dalam pelatihan penyusunan bahan ajar berbasis lectora dinyatakan sangat efektif dengan mean 24.10.

\section{Simpulan dan Saran}

Simpulan

Komponen penyelenggaraan pelatihan penyusunan bahan ajar berbasis lectora berada dalam kategori efektif $(45,01-58,50)$, pada skala (18-72) dengan mean 56,55 artinya tanggapan dari peserta dalam hal penyelenggaraan pelatihan baik untuk di selenggarakan oleh lembaga tetapi belum optimal.

Komponen kemampuan fasilitator pelatihan penyusunan bahan ajar berbasis lectora berada dalam kategori sangat efektif $(>61,75)$, pada skala (19-76) dengan mean 64,79 artinya peserta mempunyai perepsi yang sangat baik terhadap perilaku fasilitator dalam mengajar dan melatih peserta selama pelatihan sangat efektif.

Komponen hasil belajar peserta pelatihan penyusunan bahan ajar berbasis lectora berada dalam kategori efektif $(65,01$ $84,50)$, pada skala (26-104) dan mean 75,44 , artinya bahan ajar tersebut dapat digunakan atau diimplementasikan dalam proses belajar mengajar di sekolah masing-masing tetapi belum optimal.

Komponen pemenuhan kompetensi pedagogik pelatihan penyusunan bahan ajar berbasis lectora berada dalam kategori sangat efektif $(>22,75)$, pada skala (7-28) dengan mean 24,10, artinya standar kompetensi pedagogik guru terpenuhi.

Saran

Disarankan kepada lembaga untuk meningkatkan penyelenggaraan pelatihan penyusunan bahan ajar berbasis lectora, karena meskipun pelaksanaan pelatihan tersebut dikatakan efektif, namun belum optimal,

Disarankan kepada semua guru untuk menerapkan materi yang telah didapat selama mengikuti pelatihan dalam melaksanakan tugasnya sebagai guru, baik dalam menyusun bahan ajar dengan program lectora maupun pemenuhan kompetensi pedagogik, karena kedua hal tersebut sangat efektif untuk meningkatkan mutu pendidikan.

Disarankan untuk peneliti lanjutan melakukan penelitian dengan kajian yang lebih mendalam tentang keefektifan penyusunan bahan ajar berbasis lectora dengan meneliti peserta sebelum dan sesudah mengikuti pelatihan.

Disarankan untuk peneliti lanjutan menambah teknik dalam pengumpulan data yaitu dengan teknik observasi dan wawancara.

\section{Daftar Pustaka}

Arikunto, S. \& Jabar, C.S.A. (2010). Evaluasi pendidikan pendidikan. Jakarta:Bumi Aksara.

Darmawan, D. (2012). Teknologi pembelajaran. Bandung: PT Remaja Rosdakarya.

Dindikpora. (2012). Laporan panitia kegiatan pembinaan guru sekolah dasar dinas dikpora Kabupaten Sleman.

Kemendiknas .(2006). Undang- Undang RI Nomor 14, Tahun 2005, tentang Guru dan Dosen. Jakarta: CV. Laksana Mandiri.

Koufman, R. \& Thomas, S. (1980) Evaluation without fear. New York: New View Points.

Mangkuprawira, S. (2011). Manajemen sumber daya manusia strategik. Bogor: Ghalia Indonesia.

Mayer, R. E. (2005). The cambridge handbook of multimedia learning. New York: Cambridge University Press. 
Noe, R. A. (2005). Employee training and development. Singapore. Mc. Graw Hill.

Permendiknas. (2005) Peraturan Pemerintah RI Nomor 19, Tahun 2005, tentang Standar Nasional Pendidikan

Permendiknas, Peraturan Pemerintah RI Nomor 38, Tahun 1992, tentang Tenaga Kependidikan.

(2007) Nomor 16, Tahun 2007, tentang Standar Pendidik dan Kependidikan.

Sopiatin, P. (2010). Manajemen belajar berbasis kepuasan siswa. Cilegon: Ghalia Indonesia
Sugiyono, (1998). Manajemen diklat. Bandung: Alfabeta.

Sulistiyani, A.T. \& Rosidah. (2009). Manajemen sumber daya manusia. Yogyakarta: Graha Ilmu.

Usman, H. (1998). Manajemen diklat. Yogyakarta: CV Alfabeta. Bandung.

Wibawanto, H. (2002). Kemampuan dosen UNES dalam mengembangkan mengembangkan bahan ajar berbasis computer. Jurnal Pendidikan Vokasi. XVIII, 1, 19. 